\title{
Calcium and Available Phosphorus Levels for Laying Hens in Second Production Cycle*
}

Duthor(s)
Pelicia $\mathrm{K}^{1}$
Garcia $\mathrm{EA}^{2}$
Faitarone $A B \mathrm{G}^{3}$
Silva $A \mathrm{P}^{3}$
Berto $\mathrm{DA}^{3}$
Molino $\mathrm{AB}^{3}$
Vercese $\mathrm{F}^{3}$
Professor, Ph.D., Researcher of the
Department of Animal Science of the School
of Agronomy and Animal Science, José do
Rosário Vellano - UNIFENAS, Alfenas campus,
MG.
2 Associate Professor of the Department of
Animal Production, School of Veterinary
Medicine and Animal Science, UNESP,
Botucatu campus, SP.
3 Students of the Post-Graduation Program
in Animal Science of the School of Veterinary
Medicine and Animal Science, UNESP,
Botucatu campus, SP.

Mail Address

Kleber Pelícia

Rua Dr. João Candido Villas Boas, 351

Vila Pinheiro -

18609-690. Botucatu, SP, Brasil.

Tel: (14) 38825735

$38117185 / 7189$

E-mail: fokleber@hotmail.com

\section{Keywords}

Available phosphorus, egg quality, nutritional requirements, post-molting, semi-heavy layers.

\footnotetext{
Acknowledgements

The authors would like to thank Coordenação de Aperfeiçoamento de Pessoal de Nível Superior (CAPES) for financial support.

(*) Part of the thesis of the first author to obtain his Ph.D. title by the Post-Graduation Program in Animal Science of the School of Veterinary Medicine and Animal Science, UNESP, Botucatu campus, SP;

Arrived: October/2008

Approved: March/2009
}

\section{ABSTRACT}

This experiment studied the effect of four calcium $(3.0,3.5,4.0$, and $4.5 \%)$ and four available phosphorus levels $(0.25,0.30,0.35$, and $0.40 \%)$ in the diet of semi-heavy commercial layers after molting. Hisex Brown ${ }^{\circledR}$ layers between 90 and 108 weeks of age were distributed in a completely randomized experimental design with a $4 \times 4$ factorial arrangement with 16 treatments of five replicates of eight birds each. mortality, egg production, feed intake, egg mass, average egg weight, calcium and phosphorus intake, feed conversion ratio (per dozen eggs and per kg eggs), eggshell percentage and thickness, eggshell strength, eggshell weight per surface area (ESWSA), yolk percentage and color, albumen percentage, albumen and yolk heights, and blood and excreta calcium and phosphorus concentrations. There was no interaction ( $P>0.05$ ) between dietary $C a$ and avP for any of the studied parameters. There were linear increases in $\mathrm{Ca}$ intake $(\mathrm{P}<0.01)$, eggshell percentage $(P<0.05)$; ESWSA $(P<0.05)$; yolk color $(P<0.05)$; $C$ a concentration in the blood $(P<0.05)$ and excreta $(P<0.01)$ as dietary $C$ a level increased. The intake of avP linearly increased $(P<0.01)$ with dietary avP levels. The remaining parameters were not influenced $(P>0.05)$ by dietary $\mathrm{Ca}$ and avP levels. The diet containing $4.5 \%$ calcium improved feed conversion ratio per dozen eggs and eggshell quality. The lowest avP level fed $(0.25 \%)$ is sufficient to maintain the performance and the egg quality of semi-heavy commercial layers after molting.

\section{INTRODUCTION}

The nutritional role of calcium ( $\mathrm{Ca}$ ) is closely linked to that of phosphorus (P) and to the effect of vitamin D. More than $70 \%$ of animal body ashes consist of $\mathrm{Ca}$ and $\mathrm{P}$, with about $99 \%$ and $80 \%$, respectively, present in the bones (Mcdowell, 1992). The metabolic and structural function of these minerals in bone and eggshell formation is essential in poultry production (Araujo et al., 2005).

According to Berne \& Levy (1998), Ca is actively absorbed in all intestinal segments, particularly in the duodenum and the jejunum. The speed of $\mathrm{Ca}$ absorption is higher than that of any other ion, except for $\mathrm{Na}$. Animal nutritional status affects $\mathrm{Ca}$ absorption. Animal fed Cadeficient diets increase $\mathrm{Ca}$ absorption levels, whereas high dietary levels of this mineral reduce absorption.

During eggshell formation, plasmatic Ca turnover is extremely fast (1 min half-life). Ca plasma concentration rapidly decreases, stimulating the secretion of the parathyroid hormone (PTH), which almost immediately promotes an increase in bone resorption, thereby supplying the necessary $\mathrm{Ca}$ in the blood stream.

As hens age, eggshell quality is reduced, but this can be reversed by forced molting. Although this process is not fully understood, there are 
evidences that the changes in the bird body are related in vitamin $\mathrm{D}_{3}$ metabolism, particularly in the production of the metabolite $1.25(\mathrm{OH})_{2} \mathrm{D}_{3}$ in the kidneys.

PTH stimulates the synthesis -hydroxilase in the kidneys, increasing the production of $1.25(\mathrm{OH})_{2} \mathrm{D}_{3}$. This hormone or metabolite reaches the intestinal mucosa increasing $\mathrm{Ca}^{++}$by the intestine, stimulates bone resorption, reduces $\mathrm{Ca}^{++}$excretion in the urine, and induces the synthesis of $\mathrm{Ca}^{++}$-binding proteins (Ca-BP) by the enterocytes. Therefore, the homeostatic response for the increase in bone resorption is replaced by $\mathrm{Ca}$ absorption.

The establishment of $\mathrm{Ca}$ and avP requirements of commercial layers is a continuous challenge for poultry nutritionists and egg producers as the needs for these two minerals seem to constantly change. P requirements seem to be decreasing as opposed to $\mathrm{Ca}$. The reasons for these opposite directions are uncertain, but may be related to the fact that high dietary $\mathrm{Ca}$ levels reduce the need for bone resorption, therefore reducing phosphorus needs.

Hartel (1990) evaluated dietary interactions between $\mathrm{Ca}$ and $\mathrm{P}$ in high production layers and observed that there were significant performance depression and high mortality when low $P$ content was combined with high $\mathrm{Ca}$ in the diet, and that these effects were compensated when dietary $P$ content was increased. Those authors suggest that layers require $360 \mathrm{mg}$ de avP/bird/ day to supply their minimum requirements.

Part of the role of $\mathrm{P}$ during eggshell formation is to reduce blood acidosis as $P$ blood level is high, causing an increase in phosphate excretion by the kidney. During excretion, phosphate carries out $\mathrm{H}^{+}$ions, aiding the maintenance of bicarbonate levels, consequently reducing acidosis (Bertechini, 1998). On the other hand, several studies carried out at the end of the first eggproduction cycle indicate the need to reduce dietary avP levels in order to improve internal and external egg quality. Bertechini et al. (1994) studied avP intake by second-cycle commercial layers, and observed that a feeding program of two day feeding and one day fasting significantly improved eggshell quality. Rodrigues et al. (1998) verified that avP levels can be reduced from $0.35 \%$ during the peak production to $0.25 \%$ during the final production phase of layers submitted to forced molting.

During absorption, metabolism and excretion, Ca and $\mathrm{P}$ interact, establishing a ratio of approximately $2: 1$, which seldom varies (Scott et al., 1982). When there is excessive $\mathrm{Ca}$, the availability of other minerals, such as $\mathrm{P}$, magnesium, manganese, and zinc, may be affected, causing secondary deficiencies. High $\mathrm{Ca}$ intake may impact $P$ utilization due to $C a: P$ ratio changes (Anderson et al., 1995). On the other hand, high $P$ levels may also cause $C$ a deficiency.

The established adequate calcium and phosphorus levels for layers have been challenged due to the continuous advances in genetic improvement, nutrition, environment, and management. In addition, there is little information on the requirements of second-cycle layers. Studies on these requirements may have an economic impact on egg production in terms of feed cost and environment, $\mathrm{Ca}$ and $\mathrm{P}$ excretion may pollute the soil and water sources.

This study aimed at evaluating the effect of $\mathrm{Ca}$ and avP levels in second-cycle layer diets on performance, egg quality, and $\mathrm{Ca}$ and $\mathrm{P}$ excretion.

\section{MATERIAL AND METHODS}

This experiment was carried in the experimental facilities of the Poultry Sector of the School of Veterinary Medicine and Animal Science of Unesp, Botucatu campus, SP, Brazil.

A total of 640 90-week-old Hisex Brown ${ }^{\circledR}$ layers in their second production cycle was used. The experimental period was 18 weeks. Layers were housed in 80 metal cages $(100 \mathrm{~cm}$ length $\times 45 \mathrm{~cm}$ wide $x 40 \mathrm{~cm}$ height) at 8 birds per cage $\left(562.5 \mathrm{~cm}^{2} /\right.$ bird) equipped with trough feeders and nipple drinkers. The poultry house was covered with clay tiles, and contained two double rows of galvanized-iron cages separated by a $1.0 \mathrm{~m}$ aisle. A $17-\mathrm{h}$ photoperiod was applied, with artificial lighting complementing natural lighting.

Birds were distributed in a completely randomized experimental design with a $4 \times 4$ factorial arrangement: four Ca levels $(3.0,3.5,4.0$, or $4.5 \%)$ in fine particles $(0.18 \mathrm{~mm})$ and four avP levels $(0.25,0.30,0.35$, or $0.40 \%$ ), with 16 treatments of five replicates of eight birds each totaling 80 experimental units.

Birds were selected at 87 weeks of age according to uniformity, initial body weight, and egg production, and were submitted to a 7-d adaptation period.

The 16 treatments were: $3.0 \% \mathrm{Ca}$ and $0.25 \% \mathrm{P}$ (T1); 3.0\% $\mathrm{C}$ a and $0.30 \%(\mathrm{~T} 2) ; 3.0 \% \mathrm{Ca}$ and $0.35 \% \mathrm{P}$ (T3); 3.0\% Ca and $0.40 \%$ P (T4); 3.5\% Ca and $0.25 \%$ P(T5); 3.5\% C $\mathrm{C}$ and $0.30 \% \mathrm{P}(\mathrm{T} 6) ; 3.5 \% \mathrm{Ca}$ and $0.35 \%$ $\mathrm{P}$ (T7); $3.5 \% \mathrm{C}$ and $0.40 \% \mathrm{P}$ (T8); $4.0 \% \mathrm{Ca}$ and $0.25 \%$ $\mathrm{P}$ (T9); $4.0 \% \mathrm{C}$ and $0.30 \% \mathrm{P}(10) ; 4.0 \% \mathrm{Ca}$ and $0.35 \%$ $\mathrm{P}$ (T11); 4.0\% Ca and 0.40\% P (T12); 4.5\% Ca and 


\section{Pelicia K, Garcia EA, Faitarone ABG, Silva AP, Berto DA, Molino $A B$, Vercese $F$}

$0.25 \% \mathrm{P}(\mathrm{T} 13) ; 4.5 \% \mathrm{Ca}$ and $0.30 \% \mathrm{P}(\mathrm{T} 14) ; 4.5 \% \mathrm{Ca}$ and $0.35 \% \mathrm{P}(\mathrm{T} 15) ; 4.5 \% \mathrm{Ca}$ and $0.40 \% \mathrm{P}(\mathrm{T} 16)$.

Birds were offered feed and water ad libitum during the entire experimental period (90-108 weeks of age. Feeds contained equal energy $(2,750 \mathrm{kcal} \mathrm{ME} / \mathrm{kg}$ feed $)$ levels, were based on corn, soybean meal, and wheat, and were formulated to supply the nutrient requirements determined by Rostagno et al. (2005), except for $\mathrm{Ca}$ and avP. The experimental diets are shown in Table 1.

The following parameters were evaluated: mortality, egg production, feed intake, average egg weight, calcium intake, phosphorus intake, egg mass, and feed conversion ratio (per dozen egg and per kg eggs).

Mortality was daily recorded. Before submitting to analysis of variance, mortality data were transformed as $(X+0.5)^{1 / 2}$, where $X$ is mortality percentage (Steel \& Torrie, 1980).

Egg production was evaluated by dividing the average number of eggs laid per bird per week by the average number of birds multiplied by seven, and the result was multiplied by 100 . Broken and defective eggs were daily recorded in proper spreadsheets, and were evaluated as the total number of broken or defective eggs divided by the number of produced eggs, and the result was multiplied by 100 . Small and cracked eggs were classified as defective eggs.

Yolk color, as a measure of egg quality, was determined using a Roche colorimetric fan, with scores varying between 1 and 15 . Yolk percentage was
Calcium and Available Phosphorus Levels for Laying Hens in Second Production Cycle

determined dividing yolk weight by egg weight, and multiplying the result per 100 .

Albumen percentage was determined dividing albumen weight by egg weight, and multiplying the result per 100. Albumen and yolk heights were also measured.

Eggshell percentage was determined drying the eggshell in an oven at $60^{\circ} \mathrm{C}$ for three days, and allowing it to reach room temperature before weighing. It was calculated by dividing its weight by egg weight and multiplying the result per 100 .

Eggshell thickness was determined using the same shells used to determined eggshell percentage. Eggshell thickness was measured in three points at the egg equator using a pachymeter, and calculating the average among the three points.

In order to measure egg specific weight, whole eggs collected at the end of each period were immersed in graded solutions between 1.060 and $1.100 \mathrm{~g} / \mathrm{cm}^{3}$, with 0.005 difference in gradient, as recommended by Moreng \& Avens (1990).

Eggshell resistance was evaluated using whole eggs. A specific cell was coupled to the apparatus Texture Analyser TA. XT plus with a Cyl Stainless $2 \mathrm{~mm}$ probe, code $P / 2$, pre-test velocity of $2 \mathrm{~mm} / \mathrm{second}$, test velocity of $1.0 \mathrm{~mm} / \mathrm{second}$, and post-test velocity of $40 \mathrm{~mm} /$ second, recording the strength required to break the eggshell in kgf. Eggshell weight per surface area (ESWSA), expressed in $\mathrm{mg} / \mathrm{cm}^{2}$, was determined according to Abdallah et al. (1993). The following

\begin{tabular}{|c|c|c|c|c|c|c|c|c|c|c|c|c|c|c|c|c|}
\hline \multirow[t]{2}{*}{ Ingredients } & \multicolumn{14}{|c|}{ Treatments } & \multirow[b]{2}{*}{ T15 } & \multirow[b]{2}{*}{ T16 } \\
\hline & T1 & $\mathrm{T} 2$ & T3 & T4 & T5 & T6 & $\mathrm{T7}$ & T8 & T9 & T10 & T11 & T12 & T13 & T14 & & \\
\hline Corn & 49.400 & 49.510 & 49.660 & 49.790 & 51.033 & 51.200 & 51.322 & 51.444 & 52.696 & 52.836 & 52.986 & 53.150 & 54.350 & 54.476 & 54.618 & 54.756 \\
\hline Soybean meal $45 \%$ & 19.590 & 19.672 & 19.765 & 19.850 & 20.652 & 20.748 & 20.832 & 20.921 & 21.721 & 21.813 & 21.904 & 22.000 & 22.790 & 22.876 & 22.969 & 23.058 \\
\hline Wheat bran & 22.36 & 22.061 & 21.710 & 21.390 & 18.389 & 18.018 & 17.706 & 17.387 & 14.38 & 14.041 & 13.692 & 13.325 & 10.378 & 10.060 & 9.717 & 9.382 \\
\hline Calcitic limestone & 6.930 & 6.762 & 6.595 & 6.430 & 8.156 & 7.986 & 7.820 & 7.65 & 9.377 & 9.210 & 9.040 & 8.872 & 10.602 & 10.432 & 10.267 & 10.098 \\
\hline Dicalcium phosphate & 0.550 & 0.825 & 1.100 & 1.370 & 0.600 & 0.878 & 1.150 & 1.428 & 0.656 & 0.930 & 1.208 & 1.483 & 0.710 & 0.986 & 1.259 & 1.536 \\
\hline Soybean oil & 0.500 & 0.500 & 0.500 & 0.500 & 0.500 & 0.500 & 0.500 & 0.500 & 0.500 & 0.500 & 0.500 & 0.500 & 0.500 & 0.500 & 0.500 & 0.500 \\
\hline DL-methionine & 0.120 & 0.120 & 0.120 & 0.120 & 0.120 & 0.120 & 0.120 & 0.120 & 0.120 & 0.120 & 0.120 & 0.120 & 0.120 & 0.120 & 0.120 & 0.120 \\
\hline Salt & 0.350 & 0.350 & 0.350 & 0.350 & 0.350 & 0.350 & 0.350 & 0.350 & 0.350 & 0.350 & 0.350 & 0.350 & 0.350 & 0.350 & 0.350 & 0.350 \\
\hline Vitamin suppl* & 0.100 & 0.100 & 0.100 & 0.100 & 0.100 & 0.100 & 0.100 & 0.100 & 0.100 & 0.100 & 0.100 & 0.100 & 0.100 & 0.100 & 0.100 & 0.100 \\
\hline Mineral suppl. ** & 0.100 & 0.100 & 0.100 & 0.100 & 0.100 & 0.100 & 0.100 & 0.100 & 0.100 & 0.100 & 0.100 & 0.100 & 0.100 & 0.100 & 0.100 & 0.100 \\
\hline TOTAL & 100 & 100 & 100 & 100 & 100 & 100 & 100 & 100 & 100 & 100 & 100 & 100 & 100 & 100 & 100 & 100 \\
\hline \multicolumn{17}{|l|}{ Calculated nutricional levels } \\
\hline Calcium $(\%)$ & 3.000 & 3.000 & 3.000 & 3.000 & 3.500 & 3.500 & 3.500 & 3.500 & 4.000 & 4.000 & 4.000 & 4.000 & 4.500 & 4.500 & 4.500 & 4.500 \\
\hline Available phosphorus (\%) & 0.250 & 0.300 & 0.350 & 0.400 & 0.250 & 0.300 & 0.350 & 0.400 & 0.250 & 0.300 & 0.350 & 0.400 & 0.250 & 0.300 & 0.350 & 0.400 \\
\hline Metabolizable energy $(\mathrm{kca} / \mathrm{kg})$ & 2750 & 2750 & 2750 & 2750 & 2750 & 2750 & 2750 & 2750 & 2750 & 2750 & 2750 & 2750 & 2750 & 2750 & 2750 & 2750 \\
\hline Crude protein (\%) & 16.500 & 16.500 & 16.500 & 16.500 & 16.500 & 16.500 & 16.500 & 16.500 & 16.500 & 16.500 & 16.500 & 16.500 & 16.500 & 16.500 & 16.500 & 16.500 \\
\hline Dig. lysine (\%) & 0.720 & 0.720 & 0.720 & 0.720 & 0.720 & 0.720 & 0.720 & 0.720 & 0.720 & 0.720 & 0.720 & 0.720 & 0.720 & 0.720 & 0.720 & 0.720 \\
\hline Dig. Methione+cystine (\%) & 0.595 & 0.595 & 0.595 & 0.595 & 0.595 & 0.595 & 0.595 & 0.595 & 0.595 & 0.595 & 0.595 & 0.595 & 0.595 & 0.595 & 0.595 & 0.595 \\
\hline Dig. methionine (\%) & 0.354 & 0.354 & 0.354 & 0.354 & 0.354 & 0.354 & 0.354 & 0.354 & 0.354 & 0.354 & 0.354 & 0.354 & 0.354 & 0.354 & 0.354 & 0.354 \\
\hline Dig threonine (\%) & 0.537 & 0.537 & 0.537 & 0.537 & 0.537 & 0.537 & 0.537 & 0.537 & 0.537 & 0.537 & 0.537 & 0.537 & 0.537 & 0.537 & 0.537 & 0.537 \\
\hline Dig. tryptophan (\%) & 0.180 & 0.180 & 0.180 & 0.180 & 0.180 & 0.180 & 0.180 & 0.180 & 0.180 & 0.180 & 0.180 & 0.180 & 0.180 & 0.180 & 0.180 & 0.180 \\
\hline Sodium (\%) & 0.150 & 0.150 & 0.150 & 0.150 & 0.150 & 0.150 & 0.150 & 0.150 & 0.150 & 0.150 & 0.150 & 0.150 & 0.150 & 0.150 & 0.150 & 0.150 \\
\hline
\end{tabular}

*Vitamin supplement per kg feed: Vit. A - 7000 IU; Vit. D3 - 2000 IU; Vit. E - 5 mg; Riboflavin - 3 mg; Vit. K3 - 1.6 mg - Vit. B12 - 8 g; Niacin - 20 mg; pantothenic acid

- 5 mg; Antioxidant - 15 mg; choline - 250 mg. ${ }^{* *}$ Mineral supplement per kg feed: Fe - 50 mg; Cu - 8 mg; Mn - 70 mg; Zn - 50 mg; I - 1.2 mg; Se - 0.2 mg. 
Pelicia K, Garcia EA, Faitarone ABG, Silva AP, Berto DA, Molino $A B$, Vercese $F$
Calcium and Available Phosphorus Levels for Laying Hens in Second Production Cycle formula was used: ESWSA $=\{E G W /[3.9782 \times$ $\left.\left.\left(E W^{0.7056}\right)\right]\right\} \times 1000$, where: $E G W=$ eggshell weight, EW $=$ egg weight.

Blood was collected to determine calcium and phosphorus content using the method of Perkin-Eimer Corporation (1996).

Excreta were collected for $24 \mathrm{~h}$ in trays lined with plastic placed under the cages. One sample corresponded to three replicates. Excreta calcium and phosphorus percentage were determined according to the method of Lanarv (1988).

Data were analyzed using SAS (2000) statistical package, and calcium and phosphorus estimates were established using analysis of regression.

\section{RESULTS AND DISCUSSION}

Average maximum and minimum environmental temperatures during the experimental period were $30^{\circ} \mathrm{C} \pm 0.6^{\circ} \mathrm{C}$ and $22^{\circ} \mathrm{C} \pm 0.8^{\circ} \mathrm{C}$, respectively, and average maximum and minimum humidity were $84 \%$ $\pm 0.8 \%$ and $46 \% \pm 0.8 \%$, respectively.

\section{Performance}

No significant effect ( $p>0.05)$ of the interaction among factors ( $\mathrm{Ca}$ and $\mathrm{P}$ levels) was observed on layer performance.

The lack of effects ( $p>0.05)$ of the treatments on mortality are probably due to the fact that the the avP levels were not suboptimal, i.e., below the recommendations, due to the high feed intake. Sakomura et al. (1995) observed that the deficiency of available phosphorus (avP) in the diet increased bird mortality. This is due to the appearance of osteoporosis of layers kept in cages.

Table 2 shows egg production, egg weight, egg mass, feed intake, feed conversion ratio (FCR) per dozen eggs and FCR per $\mathrm{kg}$ eggs of layers fed the experimental diets.

Using the estimated linear regression equation $\mathrm{y}=$ $0.5483 x+3.4, R^{2}=0.9287$ for Ca intake as function of dietary $\mathrm{Ca}$ level, it is observed that $\mathrm{Ca}$ intake linearly increase with dietary $\mathrm{Ca}$ increase.

The prediction equation $y=0.0623 x+0.2503, R^{2}=$ 0.9981 of avP intake as a function of dietary avP also shows that when dietary avP increased, avP intake proportionally increased.

There was no significant effect ( $p>0.05)$ of dietary $\mathrm{Ca}$ or avP levels on egg production, egg weight, feed intake or feed conversion ratio per kg eggs, not a significant interaction between these two factors, as shown in Table 2. Similar findings as to Ca levels were obtained by Clunies et al. (1992a), who worked with 3.5 and $4.5 \%$ dietary $\mathrm{Ca}$. On the other hand, Rodrigues (1995), evaluating 3.8 or $4.5 \%$ dietary $\mathrm{Ca}$ in layers, found lower egg production when feeding the high Ca level, probably due to a reduction in daily feed intake, which was lower than that observed in the present experiment. Despite the lack of statistical difference, feed intake was lower when the highest Ca level was fed, and egg production numerically increased in the present experiment.

Oliveira (2001), working with avP levels of $0.21,0.27$, $0.33,0.39$, and $0.45 \%$, and Costa et al. (2004), with $0.375 \%, 0.305 \%$, and $0.235 \%$, did not observe differences in egg production. However, Barreto (1994),

\begin{tabular}{|c|c|c|c|c|c|c|c|c|}
\hline Ca level (\%) & $\begin{array}{l}\text { Egg prod. } \\
(\%)\end{array}$ & $\begin{array}{l}\text { Egg weight } \\
(\mathrm{g})\end{array}$ & $\begin{array}{l}\text { Egg mass } \\
\text { (g/hen/dia) }\end{array}$ & $\begin{array}{l}\text { Feed intake } \\
\text { (g/ hen/day) }\end{array}$ & $\begin{array}{l}\text { Ca intake } \\
\text { (g/hen/day) }\end{array}$ & $\begin{array}{c}\text { avP intake } \\
\text { (mg/hen/day) }\end{array}$ & $\begin{array}{c}\text { FCR/ } \\
\text { dozen }\end{array}$ & $\begin{array}{c}\text { FCR/ } \\
\text { kg }\end{array}$ \\
\hline 3.0 & 74.92 & 69.92 & 52.15 & 126.1 & 3.78 & 410 & 1.862 & 2.248 \\
\hline 3.5 & 78.60 & 68.07 & 53.53 & 125.0 & 4.38 & 410 & 1.759 & 2.159 \\
\hline 4.0 & 76.85 & 69.72 & 53.48 & 124.3 & 4.97 & 400 & 1.791 & 2.142 \\
\hline 4.5 & 79.15 & 68.24 & 54.00 & 123.3 & 5.55 & 400 & 1.724 & 2.114 \\
\hline \multicolumn{9}{|l|}{ avP level (\%) } \\
\hline 0.25 & 77.13 & 68.23 & 52.55 & 124.9 & 4.68 & 0.31 & 1.788 & 2.204 \\
\hline 0.30 & 78.45 & 68.16 & 53.45 & 124.9 & 4.68 & 0.37 & 1.759 & 2.172 \\
\hline 0.35 & 77.76 & 70.82 & 54.77 & 125.1 & 4.68 & 0.44 & 1.778 & 2.114 \\
\hline 0.40 & 76.17 & 68.75 & 52.38 & 123.8 & 4.63 & 0.50 & 1.795 & 2.175 \\
\hline \multicolumn{9}{|l|}{ Probability } \\
\hline Ca level & NS & NS & NS & NS & $<0.001 *$ & NS & $<0.05 * *$ & NS \\
\hline avP level & NS & NS & NS & NS & NS & $<0.001^{*}$ & NS & NS \\
\hline Interaction & NS & NS & NS & NS & NS & NS & NS & NS \\
\hline CV (\%) & 9.53 & 4.96 & 8.64 & 4.07 & 4.10 & 4.23 & 9.52 & 8.25 \\
\hline
\end{tabular}

$*(p<0.001)$ Significant linear effect; $* *(p<0.05)$ Significant cubic effect. 
using 40-week-old layers, found that $\mathrm{P}$ levels below $0.20 \%$ were not able to supply the requirements as layers aged. A $0.4 \%$ level is considered inadequate for egg production (Vandepopuliere \& Lyons, 1992). Williams (1991) asserted that avP levels can be reduced up to $0.28 \%$ in older birds. Owings et al. (1977), working with 55-week-old layers, observed lower egg production when avP levels were reduced from $0.22 \%$ to $0.11 \%$; however, they used very low avP levels as compared to the present study, which may account for the differences in egg production between these two studies.

Keshavarz \& Nakajima (1993), Oliveira et al. (1997), and Oliveira (2001) working with Ca levels between 2.80 and 4.40 also did not observe any effect on layer egg weight. As for egg mass, Araujo et al. (2005) worked with 3.5 to $4.2 \%$ Ca levels and verified that egg mass increased with increasing dietary $\mathrm{Ca}$ levels.

In terms of avP levels, Andrade et al. (2003) also did not find any effect on egg weight when feeding layers with 0.094 to 0.494 avP. On the other hand, Barreto (1994) observed that the highest egg weight was obtained when layers were fed $0.34 \%$ avP as compared to 0.15 and $0.45 \%$ avP. Frost \& Roland (1991) fed layers with $0.30,0.40$, or $0.50 \%$ avP and observed that egg weight was reduced with $0.30 \%$ avP. The differences found by Barreto (1994) and Frost \& Roland (1991) relative to the present study are probably due to the lower feed intake verified by the birds in those experiments, which therefore did not consume excessive avP. In the present study, birds with the highest feed intake consumed more avP than those of the experiments of Barreto (1994) and Frost \& Roland (1991). This excessive avP was not utilized and excreted, consequently not influencing egg weight. Daghir et al. (1985) recommended $0.25 \%$ avP as the minimum level required for average egg weight.

As to egg mass, Costa et al. (2004) also did not observe any effect of avP levels when working with levels of 0.235 to $0.375 \%$. However, Faria et al. (2000), studying $0.35,0.45$, and $0.55 \%$ avP dietary levels, verified lower feed intake and lower egg mass when $0.35 \%$ avP was fed. Araujo et al. (2005) found that feed intake decreased when $\mathrm{Ca}$ level increased from 3.5 to $4.2 \%$. This may be explained, according to Taher et al. (1984), by the fact that feed intake is reduced to maintain adequate $\mathrm{Ca}$ intake in order to maintain normal metabolic functions, which was also observed by Keshavarz (1986). Different from the present experiment, where there was no effect of $\mathrm{Ca}$ level on feed intake $(P>0.05)$, Oliveira (2001) observed a quadratic effect, with the lowest feed intake when $3.6 \%$ calcium was fed, whereas Frost \& Roland (1991) found a linear increase in feed intake as dietary Ca level increased.

There was no effect of Ca level on FCR per kg eggs, which was also observed by Araujo et al. (2005). However, Oliveira (2001) found better FCR/kg eggs when feeding $3.74 \%$ de $\mathrm{Ca}$.

The cubic regression equation $y=-0.0404 x^{3}+$ $0.3118 x^{2}-0.7593 x+2.3525, R^{2}=1$ describes the curve of FCR/dozen eggs as a function of dietary Ca level, and its respective coefficient of determination. It is observed that FCR/dozen eggs improves when dietary Ca level increased from 3.0 to $3.47 \%(F R C=1.73)$; however, FCR/dozen eggs worsened (1.76) when $\mathrm{Ca}$ levels was between 3.47 and $4.21 \%$, but improved thereafter.

Increasing dietary $\mathrm{Ca}$ levels influenced $\mathrm{FCR}$ /dozen eggs also due to the increase in blood $\mathrm{Ca}^{++}$ concentration, as shown in Table 6. These higher blood $\mathrm{Ca}^{++}$levels would limit feed intake, which, despite the lack of significant difference ( $p>0.05)$, numerically decreased as dietary $\mathrm{Ca}$ increased, thereby improving $F C R$, as observed in Table 2.

As to the effect of avP levels, Andrade et al. (2003) also did not observe effect on feed intake, feed conversion ratio per $\mathrm{kg}$ eggs or per dozen eggs, as well as Silva et al. (2004), working with avP levels of $0.094,0.294$, and $0.494 \%$. On the other hand, Araujo et al. (2005) found lower feed intake and better FCR/ $\mathrm{kg}$ eggs and dozen eggs when feeding $0.38 \%$ avP as compared to $0.30 \%$, with average feed intake of 109 and $112.4 \mathrm{~g} / \mathrm{bird}$, respectively.

Rodrigues (1995), working with de $0.25,0.35$, and $0.45 \%$ avP verified a quadratic effect on feed intake, with the highest feed intake for the $0.35 \%$ level, whereas Frost \& Roland (1991) found a linear effect of dietary $\mathrm{P}$ on feed intake.

No significant effect ( $p>0.05)$ of dietary $C a$ and avP or of their interaction on broken and defective egg percentages, as shown in Table 3.

Oliveira (2001) also did not observe dietary Ca level effects on egg loss, as well as Rodrigues (1995) as to dietary avP levels. On the other hand, Oliveira et al. (1997) detected egg loss reduction as dietary Ca levels increased.

\section{Egg external quality}

There was no effect ( $p>0.05)$ of the interaction between factors ( $\mathrm{Ca}$ and avP levels) on external egg quality. 


\section{Pelicia K, Garcia EA, Faitarone ABG, Silva AP, Berto DA, Molino $A B$, Vercese $F$}

In addition, there were no significant effects ( $p>0.05)$ of $\mathrm{Ca}$ and avP levels on egg specific weight, eggshell thickness and breaking strength, as shown in Table 4. However, dietary $\mathrm{Ca}$ levels influenced eggshell percentage and eggshell weight per surface area.

\begin{tabular}{|c|c|c|c|}
\hline Ca level (\%) & $\begin{array}{c}\text { Broken } \\
\text { eggs }^{1}(\%)\end{array}$ & $\begin{array}{l}\text { Defective } \\
\text { eggs }^{2}(\%)\end{array}$ & $\begin{array}{c}\text { Intact } \\
\text { eggs }^{3}(\%)\end{array}$ \\
\hline 3.0 & 4.19 & 1.30 & 69.44 \\
\hline 3.5 & 3.80 & 1.38 & 73.42 \\
\hline 4.0 & 4.10 & 1.37 & 71.38 \\
\hline 4.5 & 4.17 & 1.41 & 73.57 \\
\hline \multicolumn{4}{|l|}{ avP level (\%) } \\
\hline 0.25 & 4.04 & 1.44 & 71.65 \\
\hline 0.30 & 3.73 & 1.32 & 73.40 \\
\hline 0.35 & 4.13 & 1.32 & 72.31 \\
\hline 0.40 & 4.36 & 1.38 & 70.44 \\
\hline \multicolumn{4}{|l|}{ Probability } \\
\hline Ca level & NS & NS & NS \\
\hline avP level & NS & NS & NS \\
\hline Interaction & NS & NS & NS \\
\hline CV (\%) & 45.84 & 16.70 & 10.39 \\
\hline
\end{tabular}

$\mathrm{NS}=(\mathrm{p}>0.05) .1$ - Represents broken eggs. 2 - Correspond to cracked, small, and irregularly-shaped eggs. 3 - Saleable eggs.

Keshavarz \& Nakajima (1993) also did not observe any effect of 3.5 or $4.5 \%$ dietary Ca on egg specific weight. Conversely, Albano Jr. et al. (2000) verified lower egg specific weight when feeding 2 and $3 \% \mathrm{Ca}$ relative to 4, 5, and $6 \% \mathrm{Ca}$, and Araujo et al. (2005) obtained higher specific egg weight with higher dietary Ca levels.

As for dietary P, Rodrigues (1995) and Araujo et al. (2005) did not observe any effect on egg specific weight, whereas Miles et al. (1983) determined that
Calcium and Available Phosphorus Levels for Laying Hens in Second Production Cycle

total $\mathrm{P}$ levels higher than $0.5 \%(0.7,1.5$, and $2.3 \%)$ were inversely related to egg specific weight, and that Ca levels below $0.3 \%$ ( 0.23 and $0.17 \%$ ) produced the worst results. Junqueira et al. (1984) reported reduced specific egg weight when layers were fed $0.3 \%$ total $\mathrm{P}$ as compared to $0.6 \%$.

Miles et al. (1983) showed that egg specific weight was inversely proportional to dietary avP levels, and reported that high $P$ plasma concentration resulting from high dietary $P$ depress bone mobilization, and therefore, reduce egg specific weight. This probably was not the case in the present experiment, as blood $P$ concentration did not change (Table 6).

Sohail \& Roland (2002), working with 0.1 to $0.7 \%$ P levels, observed that the lowest dietary avP level resulted in the lowest plasma $P$ concentration and lowest egg specific weight, suggesting an association between blood $\mathrm{P}$ levels and egg specific weight.

Rodrigues (1995) also did not observe any effect of Ca levels on eggshell thickness. On the other hand, Rodrigues et al. (2005) found that 3.5\% dietary $\mathrm{Ca}$ increased eggshell thickness as compared to $2.0 \% \mathrm{Ca}$.

In terms of dietary P, Daghir et al. (1985) verified higher eggshell thickness when the diet contained $0.35 \%$ or lower avP levels, whereas Rodrigues (1995), Faria et al. (2000), and Sakomura et al. (1995), working with 0.14 to $0.44 \%$ dietary avP did not observe any differences in eggshell thickness.

The obtained linear regression equation $y=0.119 x$ $+8.9985, R^{2}=0.8992$ shows that eggshell percentage increased with increasing dietary Ca levels. Oliveira (2001) did not observe any effects of dietary Ca levels on eggshell percentage; however, feed intake was also reduced in that experiment.

\begin{tabular}{|c|c|c|c|c|c|}
\hline Ca level (\%) & $\begin{array}{c}\text { Specific weight } \\
\left(\mathrm{g} / \mathrm{cm}^{3}\right)\end{array}$ & $\begin{array}{c}\text { Eggshell } \\
\text { thickness }(\mathrm{mm})\end{array}$ & $\begin{array}{c}\text { Eggshell } \\
(\%)\end{array}$ & $\begin{array}{c}\text { EGWSA } \\
\left(\mathrm{mg} / \mathrm{cm}^{2}\right)\end{array}$ & $\begin{array}{c}\text { Eggshell } \\
\text { strength (gF) }\end{array}$ \\
\hline 3.0 & 1.087 & 0.77 & 9.13 & 79.62 & 2318.3 \\
\hline 3.5 & 1.088 & 0.64 & 9.30 & 82.77 & 2448.2 \\
\hline 4.0 & 1.087 & 0.64 & 9.35 & 82.81 & 2452.2 \\
\hline 4.5 & 1.089 & 0.64 & 9.53 & 84.90 & 2429.5 \\
\hline \multicolumn{6}{|l|}{ avP level(\%) } \\
\hline 0.25 & 1.089 & 0.65 & 9.51 & 83.38 & 2384.0 \\
\hline 0.30 & 1.087 & 0.63 & 9.24 & 82.04 & 2437.2 \\
\hline 0.35 & 1.087 & 0.77 & 9.28 & 81.90 & 2427.3 \\
\hline 0.40 & 1.088 & 0.64 & 9.29 & 82.78 & 2399.8 \\
\hline \multicolumn{6}{|l|}{ Probability } \\
\hline Ca level & NS & NS & $p<0.05^{*}$ & $p<0.05^{*}$ & NS \\
\hline avP level & NS & NS & NS & NS & NS \\
\hline Interaction & NS & NS & NS & NS & NS \\
\hline CV (\%) & 0.26 & 46.61 & 3.98 & 4.11 & 19.45 \\
\hline
\end{tabular}

\footnotetext{
*Significant linear effect $(p<0.05)$.
} 
Albano Jr. et al. (2000) found that 5 and 6\% Ca in the diet of white layers post-molting promoted higher eggshell percentage as compared to 2 and $3 \%$, and that 3 and $4 \%$ dietary $\mathrm{Ca}$ increased eggshell percentage as compared to $2 \%$, indicating that positive responses were obtained as dietary Ca levels increased.

Nascif et al. (2004) fed layers pre-laying diets containing $0.8,1.8$, and $2.8 \% \mathrm{Ca}$, and found that $2.8 \%$ Ca resulted in higher eggshell percentage as compared to $1.8 \% \mathrm{Ca}$.

The increase in eggshell percentage as dietary $\mathrm{Ca}$ level increased observed in the present experiment may have resulted from the possible increase in eggshell Ca content. Positive Ca balance may be beneficial for future quality of the eggshell. Gilbert et al. (1981) asserted that, during egg production, the main factor for eggshell quality maintenance seems to be the maintenance of positive $\mathrm{Ca}$ balance. In the present study, eggshell percentage was lower in layers fed $3.0 \% \mathrm{Ca}$ as compared to $4.5 \% \mathrm{Ca}$. A $3.0 \%$ dietary Ca level seems to be insufficient, and therefore more $\mathrm{Ca}$ $(4.5 \%)$ should be fed in order to have reasonable eggshell quality.

Oliveira (2001) worked with 72- to 88-week-old second cycle layers and observed a quadratic effect of dietary $\mathrm{Ca}$ levels on eggshell percentage, with the highest percentage obtained with $2.8 \% \mathrm{Ca}$ as compared to $3.2,3.6,4.0$, and $4.4 \% \mathrm{Ca}$, and a positive linear effect of dietary $\mathrm{Ca}$ level on eggshell percentage during the fourth period. On the other hand, Chowdhury \& Smith (2002) did not observe any effects of dietary Ca levels between 2.5 and $4.0 \%$ on eggshell weight, which may be justified by the feed intake obtained in this study.

Sakomura et al. (1995) also did not find effects of avP levels on eggshell percentage, while Junqueira (1993) suggests that excessive dietary $P$ may reduce eggshell percentage.

The obtained linear regression equation $y=1.5879 x$ $+78.556 ; R^{2}=0.886$ shows that eggshell weight per surface area (ESWSA) increases or improves as dietary Ca levels increase. Oliveira (2001) fed similar Ca levels $(2.8,3.2,3.6,4.0$, and $4.4 \%)$ to commercial layers, but did not verify any effect on ESWSA. A possible reason for this difference may layer age: despite also having worked with second-cycle layers, Oliveira (2001) used 72- to 88-week-old hens, whereas in the present experiment, birds were older (88 weeks of age) at the beginning of the experimental period, and therefore, due to their higher Ca requirements, responded better to dietary $\mathrm{Ca}$ in terms of eggshell weight per surface area. These differences among studies demonstrate the importance of determining the nutritional requirements of commercial layers as a function of bird age.

The increase in ESWSA may be explained by the study of Vicenzi (1996) who found that excessive dietary Ca increased $C$ a deposits in the egg, thereby increasing ESWSA. Another hypothesis is that the increase in eggshell weight and ESWSA observed in the present study is that the high plasma Ca concentrations stimulated biochemical reactions (increase of $1,25(\mathrm{OH})_{2} \mathrm{D}_{3}$ in the kidneys), which increase blood $\mathrm{Ca}^{++}$ level, and this additional blood $\mathrm{Ca}^{++}$may be used for eggshell calcification. Independent of dietary Ca level, a fraction of $\mathrm{Ca}$ will always be removed from the bones; in case of Ca deficiency in the diet, more Ca will be removed, resulting in osteopenia (Berne \& Levy, 1998).

As to P levels, Oliveira (2001) and Rodrigues (1995) also did not observe effects on ESWSA. However, Rodrigues (1995) observed a quadratic effect of $P$ levels, with the highest eggshell weight per surface area obtained with $0.38 \%$ avP.

$\mathrm{Ca}$ and $\mathrm{P}$ are required in adequate amounts, as their excess or deficiency results in eggshell defects (Junqueira \& Rodrigues, 2004). In the present study, no differences in eggshell strength were detected, even in birds fed low Ca levels. This is probably explained by the fact that, in Ca-deficient diets, there is a better utilization of $\mathrm{Ca}$ due to better intestinal absorption efficiency (Hamilton \& Cipera, 1981). On the other hand, Keshavarz (2002) reported that adequate body $P$ status is maintained even when levels below those recommended are fed.

In terms of egg external quality, the use of $4.5 \%$ dietary $\mathrm{Ca}$ is recommended, as this level increased eggshell percentage and eggshell weight per surface area, as well as $0.25 \%$ avP (the lowest used in the present experiment), because no improvements were detected as dietary $\mathrm{P}$ level increased.

\section{Egg internal quality}

No significant effects ( $p>0.05)$ of dietary $\mathrm{Ca}$ and avP, nor of the interaction between $\mathrm{Ca}$ and avP levels were observed on yolk \%, albumen \%, or Haugh units (Table 5). However, dietary Ca levels affected yolk color.

The linear regression equation obtained for orange intensity of the yolk color $y=0.0746 x+6.402, R^{2}=$ 0.9884 shows that the intensity of orange in the yolk increases with increasing dietary Ca levels.

Albano Jr et al. (2000) also observed that 2 and 6\% 


\begin{tabular}{|c|c|c|c|c|}
\hline Ca level (\%) & Yolk (\%) & Yola color* & Albumen (\%) & Haugh units \\
\hline 3.0 & 24.83 & 6.47 & 66.05 & 82.46 \\
\hline 3.5 & 24.92 & 6.57 & 65.78 & 81.80 \\
\hline 4.0 & 25.12 & 6.62 & 65.56 & 81.00 \\
\hline 4.5 & 24.87 & 6.70 & 66.04 & 81.26 \\
\hline \multicolumn{5}{|l|}{ avP level (\%) } \\
\hline 0.25 & 24.83 & 6.59 & 65.77 & 82.60 \\
\hline 0.30 & 24.92 & 6.63 & 66.15 & 81.05 \\
\hline 0.35 & 25.12 & 6.57 & 65.81 & 81.00 \\
\hline 0.40 & 24.87 & 6.56 & 65.67 & 81.88 \\
\hline \multicolumn{5}{|l|}{ Probability } \\
\hline Ca level & NS & $p<0.05^{*}$ & NS & NS \\
\hline avP level & NS & NS & NS & NS \\
\hline Interaction & NS & NS & NS & NS \\
\hline CV (\%) & 6.46 & 3.32 & 1.74 & 4.75 \\
\hline
\end{tabular}

*Significant linear effect.

dietary Ca reduced yolk color intensity as compared to 3,4 , and $5 \% \mathrm{Ca}$. This indicates that there is an optimal Ca level, between 3 and 5\%, for yolk color in commercial layer production. Hurwitz (1987) reported that $\mathrm{Ca}$ regulates some important biological processes, such as the transference of cell information, hormone biosynthesis and release, and cell replication and differentiation. The higher blood $\mathrm{Ca}^{++}$concentrations (Table 6) resulting from higher dietary Ca levels may have influenced metabolic processes that resulted in the more intense yolk color observed in the present study.

It was expected that increasing dietary avP levels would increase yolk \% as most of the phosphorus used during egg formation is incorporated to the yolk as phospholipids and phosphoproteins. Nevertheless, not even the highest dietary avP level changed blood $P$, as shown in Table 6 , which may explain the lack of dietary $\mathrm{P}$ level on yolk \%.

Costa et al. (2004) also did not observe any effects of $0.235,0.305$, and $0.375 \%$ avP on yolk $\%$, as well as Oliveira (2001), who did not detect any effects of dietary $\mathrm{Ca}$ and avP levels on yolk \% or Haugh units. On the other hand, Albano Jr et al. (2000) found that 2 and $4 \%$ dietary Ca promoted higher Haugh units ( $\mathrm{HU})$ as compared to $5 \% \mathrm{Ca}$, whereas 3 and $6 \%$ dietary $\mathrm{Ca}$ were not different from the other levels.

Rodrigues (1995) verified a quadratic effect of avP on $\mathrm{HU}$, with $0.25 \%$ avP promoting the highest $\mathrm{HU}$.

The results obtained in the present study indicate that $4.5 \%$ dietary Ca is recommended to obtain a more intense orange yolk, whereas the lowest avP level $(0.25 \%)$ can be used, as there was no change in egg internal quality parameters with higher dietary avP levels, possibly due to P loss in the excreta.

\section{Blood and feces calcium and phosphorus concentrations}

Table 6 shows the determined $\mathrm{Ca}$ and avP concentrations in the blood and in the excreta of layers fed different $\mathrm{Ca}$ and $\mathrm{P}$ levels.

Dietary $\mathrm{Ca}$ level significantly influenced $\mathrm{Ca}$ blood concentration, which, however, was not affected by avP level or by the interaction between $\mathrm{Ca}$ and avP, as shown in Table 6.

The determined linear regression equations of the effect of dietary $\mathrm{Ca}$ on blood $\mathrm{Ca}$ concentration ( $\mathrm{y}=$ $\left.1.2337 x+14.06 ; R^{2}=0.944\right)$ and on excreta $\mathrm{Ca}$ concentration $\left(y=0.9572 x+2.491 ; R^{2}=0.8902\right)$ show that both blood and excreta Ca concentrations linearly increase as dietary $\mathrm{Ca}$ levels increased.

Hurwitz \& Bar (1967), working with 3.72 and $3.79 \%$ calcium levels, and Clunies et al. (1992b), with 2.5, 3.5, and $4.5 \% \mathrm{Ca}$, reported that total $\mathrm{Ca}$ retention by the bird increased with dietary Ca levels. On the other hand, Kimberg et al. (1961) observed that Ca transport in the digestive tract increased when low $\mathrm{Ca}$ levels $(2.8 \%)$ were fed.

The role of dietary Ca level depends on the age of the bird, which was shown in the present study, where a better response to increasing dietary $\mathrm{Ca}$ level as compared to some of the mentioned studies using younger layers.

Silva et al. (2004) did not observe any effects on blood $\mathrm{P}$ concentrations when feeding hens 0.094 , 0.294 , or $0.494 \%$ avP, nor Andrade et al. (2003) who used $0.094,0.194,0.294,0.394$, or $0.494 \%$ avP. However, Sohail et al. (2001) found that reducing dietary avP promoted a decrease in blood $\mathrm{P}$ levels, observing differences when 0.09 and $0.45 \%$ avP were fed. Keshavarz (2000) fed layers with 0.30, 0.35, and 


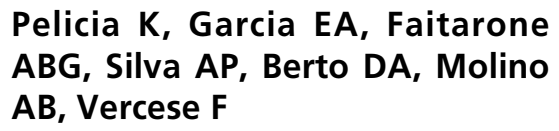

\begin{tabular}{|c|c|c|c|c|}
\hline Ca level $(\%)$ & Blood Ca conc. (mg/ 100mL)* & Blood P conc. (mg/ 100mL) & Excreta Ca conc. (\%)* & Excreta P conc. (\%) \\
\hline 3.0 & 14.98 & 11.91 & 3.17 & 1.52 \\
\hline 3.5 & 17.09 & 11.36 & 4.56 & 1.59 \\
\hline 4.0 & 17.59 & 11.96 & 5.91 & 1.65 \\
\hline 4.5 & 18.92 & 11.84 & 5.91 & 1.47 \\
\hline \multicolumn{5}{|l|}{ avP level(\%) } \\
\hline 0.25 & 17.65 & 11.86 & 5.11 & 1.46 \\
\hline 0.30 & 17.70 & 11.99 & 4.93 & 1.46 \\
\hline 0.35 & 15.94 & 11.75 & 4.01 & 1.55 \\
\hline 0.40 & 17.28 & 11.47 & 5.49 & 1.76 \\
\hline $\begin{array}{l}\text { Ca level } \\
\text { Crobabilty }\end{array}$ & $p<0.05^{*}$ & NS & \multicolumn{2}{|c|}{ Probability } \\
\hline avP level & NS & NS & NS & NS \\
\hline Interaction & NS & NS & NS & NS \\
\hline CV $(\%)$ & 17.01 & 12.20 & 27.22 & 26.08 \\
\hline
\end{tabular}

*Significant linear effect.

$0.40 \%$ avP and did not detect any differences in $\mathrm{P}$ excretion or blood $\mathrm{P}$ content. These observations suggest the the lowest avP level used in the present study $(0.25$ $\%$ ) did not cause any problems because this level is not much lower than the recommendations and because the higher feed intake resulted in higher $\mathrm{P}$ intake, differently from the findings of Sohail et al. (2001).

In the present experiment, as dietary $\mathrm{Ca}$ levels increased, the birds used part of it and excreted the excess, despite the increase in blood $\mathrm{Ca}$ concentration. This is explained by the fact that there two calcium absorption pathways: one is saturable, and the other not (Bronner, 1987). The saturable pathway requires Ca-binding proteins, which amount is constant in the epithelial cells. Therefore, when low Ca levels are fed, the ratio between the binding protein and $\mathrm{Ca}$ is higher, promoting higher $\mathrm{Ca}$ digestibility. Hamilton \& Cipera (1981) found that in Ca-deficient diets, there is higher Ca utilization due to higher efficiency of intestinal absorption. However, it must be stressed that $\mathrm{Ca}$ interacts with $\mathrm{P}$, and deficiencies or excesses of one of them affects the utilization of the other.

There was no effect of dietary avP level on blood avP concentration, which may explained by the numerical increase of $P$ loss in the excreta as dietary avP level increased. $P$ loss in the excreta was not significant due to its high coefficient of variation.

\section{CONCLUSIONS}

The diet containing $4.5 \%$ calcium improved feed conversion ratio per dozen eggs and eggshell quality. The lowest avP level fed $(0.25 \%)$ is sufficient to maintain the performance and the egg quality of semiheavy commercial layers after molting.

\section{REFERENCES}

Abdallah AG, Harms RH, El-Husseiny O. Various methods of measuring shell quality in relation to percentage of cracked eggs. Poultry Science 1993; 72(11):2038-2043.

Albano Junior $M$. et al. Desempenho e qualidade dos ovos de diferentes linhagens de poedeiras comerciais pós-muda forçada recebendo rações com níveis variáveis de cálcio. Brazilian Jounal Veterinary Research Animal Science 2000; 37(4).

Anderson $\mathrm{KE}$, Harvenstein $\mathrm{GB}$, Brake J. Effects of strain and rearing dietary regimens on brown-egg pullet growth and strain, rearing dietary regimens, density, and feed space effects on subsequent laying performance. Poultry Science 1995; 74:1079-1092.

Andrade IS. et al. Níveis de fósforo e de fitase em rações para poedeiras semipesadas à base de milho e farelo de soja [CD-ROM]. Anais da 40th Reunião Anual da Sociedade Brasileira de Zootecnia; 2003; Santa Maria, Rio Grande do Sul. Brasil: Sociedade Brasileira de Zootecnia; 2003.

Araújo JA. et al. Níveis de cálcio, fósforo disponível e de fitase na dieta de poedeiras após a muda forçada [CD-ROM]. Anais da 42th Reunião Anual da Sociedade Brasileira de Zootecnia; 2005; Goiânia, Goiás. Brasil: Sociedade Brasileira de Zootecnia; 2005.

Barreto SLT. Efeito de níveis de fósforo disponível durante o pico de postura para duas linhagens de poedeiras comerciais leves [dissertação]. Lavras: Universidade Federal de Lavras; 1994.

Berne MR, Levy MN. Fisiologia. 4th ed. Rio de Janeiro: Guanabara Koogan; 1998.

Bertechini AG. et al. Efeitos da restrição de fósforo para poedeiras comerciais de $2^{\circ}$ ciclo sobre o desempenho e qualidade da casca do ovo. Anais da 12th Conferencia Apinco de Ciência e Tecnologia Avícolas; 1994; Campinas, São Paulo. Brasil: Fundação APINCO de Ciência e Tecnologia Avícolas; 1994. p. 37-38.

Bertechini AG. Nutrição de monogástricos [trabalho de conclusão de curso]. Brasília: Associação Brasileira de Educação Agrícola 


\section{Pelicia K, Garcia EA, Faitarone ABG, Silva AP, Berto DA, Molino $A B$, Vercese $F$}

Superior; 1998.

Bronner F. Intestinal calcium absorption: mechanisms and applications. Journal Nutrition 1987; 117:1347-1352.

Card LE, Nesheim MC. Produccion avícola. Zaragoza: Acribia; 1968. Chowdhury SR, Smith TK. Dietary interaction of 1,4-diaminobutane (putrescine) and calcium on eggshell quality and performance in laying hens. Poultry Science 2002; 81:84-91.

Clunies M, Parks D, Leeson S. Calcium and phosphorus metabolism and eggshell formation of hens fed different amounts of calcium. Poultry Science 1992b; 71:482-489.

Clunies M, Parks D, Leeson S. Calcium and phosphorus metabolism and eggshell thickness in laying hens producing tick or thin shells. Poultry Science 1992a; 71(3):490-498.

Costa FGP. et al. Níveis de fósforo disponível e de fitase na dieta de poedeiras de ovos de casca marrom. Ciência Animal Brasileira 2004; 5:73-81.

Daghir NJ, Farran MT, Kaysi JA. Phosphorus requirements of laying hens in a semiarid continental climate. Poultry Science $1985 ; 64(7)$ : 1382-84.

Faria DE. de. et al. Efeito de diferentes níveis de sódio e fósforo sobre o desempenho e a qualidade da casca dos ovos de poedeiras comerciais. Revista Brasileira de Zootecnia 2000; 29(2):458-466.

Frost TJ, Roland DA. The influence of various calcium and phosphorus levels on tibia strength and eggshell quality of pullets during peak production. Poultry Science 1991; 70(40):963-969.

Gilbert AB, Peddie J, Mitchell GG, Teague PW. The egg laying response of the domestic hen to variation in dietary calcium. British Poultry Science 1981; 22:537-548.

Hamilton RMG, Cipera JD. Effects dietary calcium levels during the brooding, rearing, and early laying period on feed intake, egg production, and shell quality of white leghorn hens. Poultry Science $1981 ; 60(2): 349-357$.

Hartel H. Evaluation of the dietary interaction of calcium and phosphorus in the high producing laying hen. British Poultry Science 1990; 31(3):473-494.

Hurwitz S. Effect of nutrition on egg quality. In: Wells RG, Belyavin CG. Egg quality current problems and recent advances. London: Butterworths; 1987. p. 1522-1527.

Hurwitz S, Bar A. Calcium metabolism of hens secreting heavy or light egg shells. Poultry Science 1967; 46:1522-1527.

Junqueira OM, Harms RH. Influência dos níveis energéticos e do fósforo sob o desempenho de poedeiras comerciais. Ars Veterinária 1993; 9(1):46-53.

Junqueira OM, Costa PT, Miles RD. Interrelationship between sodium chloride, sodium bicarbonate, calcium and phosphorus in laying hen diets. Poultry Science 1984; 63(2):123-30.
Junqueira OM, Rodrigues EA. Balanço de cálcio e fósforo em poedeiras comerciais. In: Berchieri Junior A. Atualização em avicultura para poedeiras comerciais. Jaboticabal: Funep; 2004. p. 107-20.

Kehavarz K. Nonphytate phosphorus requirement of laying hens with and without phytase on a phase feeding program. Poultry Science 2002; 79:613-798.

Kehavarz K, Nakajima S. Re-evaluation of calcium and phosphorus requirements of laying hens for optimum performance and eggshell quality. Poultry Science 1993; 72(1):144-153.

Keshavarz K. Reevaluation of nonphytate phosphorus requirement of growing pullets with and without phytase. Poultry Science 2000; 79:1143-53.

Keshavarz K. The effect of dietary levels of calcium and phosphorus on performance and retention of these nutrients by laying hens. Poultry Science 1986; 65(1):114-121.

Kimberg DV, Schachter D, Schenker H. Active transport of calcium by intestine: Effect of dietary calcium. American Journal Physiology 1961; 200:1256-1262.

Laboratório Nacional de Referência Vegetal. Análises de corretivos, fertilizantes e inoculantes métodos oficiais. Brasília: Ministério da Agricultura, Secretaria Nacional de Defesa Agropecuária; 1988.

McDowell LR. Calcium and phosphorus. In: McDowell LR. Books. Vitamins in animal nutrition. London: Academic Press; 1992. p. 2677.

Miles RD, Costa PT, Harms RH. The influence of dietary phosphorus level on laying hen performance, eggshell quality, and various blood parameters. Poultry Science 1983; 62(6):1033-1037.

Moreng RE, Avens JS. Ciência e produção de aves. São Paulo: Roca; 1990.

Nascif CCC. et al. Níveis de cálcio, de fósforo e de proteína para poedeiras leves no período de pré- postura, e seus efeitos no período de 26 a 29 semanas de idade [CD-ROM]. Anais da 41th Reunião Anual da Sociedade Brasileira de Zootecnia; 2004; Campo Grande, Mato Grosso do Sul. Brasil: Sociedade Brasileira de Zootecnia; 2004.

Oliveira JEF, Oliveira BL, Bertechini AG. Níveis de cálcio granulometria e horário de fornecimento de calcário no desempenho e na qualidade do ovo de poedeiras leves no segundo ciclo de postura. Ciência e Agrotecnologia 1997; 21:502-510.

Oliveira JR. Níveis de cálcio e de fósforo em dietas de poedeiras leves e semipesadas no segundo ciclo de produção [dissertação]. Lavras: Universidade Federal de Lavras; 2001.

Owings WJ, Sell JL, Balloun SL. Dietary phosphorus needs of laying hens. Poultry Science 1977; 56:2056-2066.

Perkin-Eirmen Corporation. Anatomic absorption spectroscopy analytical methods. Norwalk; 1996. 


\section{Pelicia K, Garcia EA, Faitarone ABG, Silva AP, Berto DA, Molino $A B$, Vercese $F$}

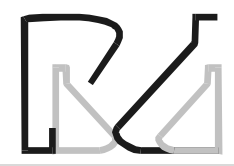

Calcium and Available Phosphorus Levels for Laying Hens in Second Production Cycle

Rodrigues EA. et al. Níveis de cálcio em rações de poedeiras comerciais no segundo ciclo de postura. Acta Scientiarum Animal Sciences 2005; 27(1):49-54.

Rodrigues PB. et al. Fatores nutricionais que influenciam a qualidade do ovo no segundo ciclo de produção. 2. Níveis de fósforo disponível. Revista Brasileira de Zootecnia 1998; 27(1):143-149.

Rodrigues PB. Fatores nutricionais que afetam a qualidade do ovo de poedeiras de $2^{\circ}$ ciclo [dissertação]. Lavras: Universidade Federal de Lavras; 1995.

Rostagno HS. et al. Tabelas brasileiras para aves e suínos: composição de alimentos e exigência nutricionais. Viçosa: Universidade Federal de Viçosa; 2005.

Sakomura NK. et al. Exigências nutricionais de fósforo para galinhas poedeiras. Revista Brasileira de Zootecnia 1995; 24(6):936-951.

Silva JHV. et al. Efeito do fósforo disponível e da fitase sobre o desempenho, níveis de fósforo plasmático e teor de cinzas nos ossos de poedeiras semipesadas. Anais da 22th Conferência Apinco de Ciência e Tecnologia Avícola; 2004; Santos, São Paulo. Brasil: Fundação APINCO de Ciência e Tecnologia Avícola; 2004. p.94.

Sohail SS, Roland DA. Metabolism and nutrition: Influence of Dietary Phosphorus on Performance of Hy-Line W36 Hens. Poultry Science 2002; 81:75-83.

Sohail SS. et al. Influence of cage density and prior dietary phosphorus level on phosphorus requirement of commercial leghorns, Poultry Science 2001; 80:769-775.

Statistical Analyses System. User's guide (CD-ROM]. Cary; 2000.

Steel RGD, Torrie JH. Principles and procedures of statistics. New York: Mcgraw-Hill; 1980.

Taher Al, Gleaves EW, Beck M. Special calcium appetite in laying hens. Poultry Science 1984; 63:2261-2267.

Teeter RG. Estresse calórico em frangos de corte. Anais da 8th Conferênia Apinco de Ciência e Tecnologia Avícolas; 1990; Campinas, São Paulo. Brasil: Fundação APINCO de Ciência e Tecnologia Avícola; 1990. p. 33-44.

Vandepopuliere JM, Lyons JJ. Effect of inorganic phosphate source and dietary phosphorus level on laying hen performance and eggshell quality. Poultry Science 1992; 71:1022-1031.

Vicenzi E. Fadiga de gaiola e qualidade da casca do ovo - aspectos nutricionais. Anais da 6th Simpósio Técnico de Produção de Ovos; 1996; São Paulo, São Paulo. Brasil: APA; 1996. p. 77-91.

Willians W. Nutrição relacionada com a qualidade do ovo e produtividade. Simpósio Técnico de Produção de Ovos; 1991; Campinas, São Paulo. Brasil: APA; 1991. p. 86-91. 